\title{
EXPERIMENTAL STUDY OF THE ANTI-SEEPAGE CHARACTERISTICS OF SIDRATON PARTICLES
}

\section{EKSPERIMENTALNA ŠTUDIJA KARAKTERISTIK ZAŠČITE PROTI PRONICANJU SIDRATONSKIH DELCEV}

\author{
Yue Liang1,2,3*, Qi Wei ${ }^{1,2}$, Chen Ma ${ }^{1,2}$, Pengfei Chen ${ }^{1,2}$, Dehong Yang ${ }^{3}$, Wei Xiong ${ }^{3}$ \\ ${ }^{1}$ National Engineering Research Center for Inland Waterway Regulation, Chongqing Jiaotong University, Chongqing, China \\ ${ }^{2}$ School of River and Ocean Engineering, Chongqing Jiaotong University, Chongqing, China \\ ${ }^{3}$ CCCC THCQ Ecological Restoration Research Institute Co., Ltd., C, Chongqing, China
}

Prejem rokopisa - received: 2020-03-04; sprejem za objavo - accepted for publication: 2020-07-15

doi: $10.17222 /$ mit. 2020.040

\begin{abstract}
Leakage is a common safety problem of embankment dams and levees. Leakage not only causes a loss of water, but also leads to potential failure of various mechanisms such as internal erosion. This study introduces a newly developed anti-seepage material, i.e., the Sidraton particles, that can be used for leakage repairs. The Sidraton particles are composed of quartz cores, bentonite and a polymer-binder coating on them. The Sidraton particles hydrate when they meet water, subsequently functioning as an anti-seepage barrier. For this study, eighteen laboratory experiments were carried out with a pressure-controlled apparatus to investigate the anti-seepage characteristics of hydrated Sidraton particles. The study focuses on the effects of the stress and the fraction of added sand. The experiment results reveal that hydrated Sidraton particles exhibit the favorable anti-seepage ability and high stress sensitivity. The effects of adding sand are also significant for the permeability of the hydrated particles. The advantages of an anti-seepage structure composed of Sidraton particles are also confirmed by comparing them to the traditional leakage-proofing materials such as natural clay and an HDPE film. These advantages include an extremely low permeability, the coordinated-deformation ability and the self-repairing ability. Because of these characteristics, the Sidraton-particle material can play an important role in anti-seepage projects including the leakage repairs of embankment dams and levees.

Keywords: Sidraton particles, anti-seepage characteristics, stress state, hydraulic conductivity
\end{abstract}

Puščanje vode je glavni problem nasipov, nabrežin in rečnih pregrad. Netesnost ne povzroča samo izgub vode temveč lahko vodi tudi do poškodb z različnimi mehanizmi kot je interna erozija. V tej študiji avtorji tega članka uvajajo nov material, ki preprečuje prepuščanje. To so Sidratonski delci, ki se lahko uporabljajo pri popravilu netesnosti. Sidratonski delci so sestavljeni iz kremenovih jeder, bentonita in na njih polimernega veziva. Sidratonski delci hidratizirajo, ko se srečajo z vodo in takoj delujejo kot bariera, ki preprečuje pronicanje. Avtorji te študije so izvedli osemnajst (18) laboratorijskih preizkusov z aparatom, ki mu je mogoče kontrolirano spreminjati tlak. Na ta način so lahko ugotavljajli krakteristike pronicanja vode skozi hidratizirane Sidratonske delce. Studirali so vpliv napetosti in deleža delcev v peščeni mešanici. S preiskusi so dokazali, da hidratizirani Sidratonski delci učinkovito preprečujejo pronicanje vode in so učinkoviti tudi pri visokih napetostih. Učinek dodatka peska je prav tako pomemben za propustnost hidratiziranih delcev. V primerjavi z drugimi tesnilnimi materiali (glina, HDPE-film) imajo zaradi svoje strukture Sidratonski delci določene prednosti. Tako imajo ekstremno majhno permeabilnost, sposobnost koordinirane deformacije in sposobnost samo obnavljanja. Zaradi teh lastnosti lahko Sidratonski delci v bodoče odigrajo pomembno vlogo pri projektih odprave pronicanja in prepuščanja vode na nasipih in drugih vodnih zajetjih.

Ključne besede: Sidratonski delci, lastnosti pronicanja, napetostno stanje, hidravlična prevodnost

\section{INTRODUCTION}

Leakage is a major safety issue of embankment dams and levees. ${ }^{1,2}$ In addition to causing an extra loss of the water storage in reservoirs, leakage may result in dam failure due to various mechanisms such as internal erosion. ${ }^{3}$ Internal erosion is responsible for about half of the embankment-dam failures according to the statistics. ${ }^{4}$ Therefore, investigating and repairing the leakage of embankment dams and levees are crucial not only for the economy but also for the safety issues. The investigation of leakage is extensively progressing with the rapid developing of the geodesic physical detecting approaches such as the high-density resistivity method, ${ }^{5}$ the transient electromagnetic method, the flow-field method ${ }^{6}$ and the electrical-resistivity tomography. ${ }^{7-10}$ The structures and

*Corresponding author's e-mail:

liangyue2560@163.com (Yue Liang) the materials used to prevent and repair dam leakage are also developing. Curtain grouting and a concrete wall are the common methods and structures used for stopping seepage and leakage of the existing dams and those under construction. ${ }^{11}$ The high-density polyethylene (HDPE) geomembrane and its multilayer structure are developed and applied in anti-seepage projects involving reservoirs and landfills. ${ }^{12}$ In recent years, researchers have produced some new synthetic anti-seepage materials as well. For example, Y. Gao, et al. ${ }^{13}$ used microbial-induced calcite precipitation to reduce the pore volume and soil permeability. Four different treatment schemes were used to treat experimental soil. The results showed that the pore volume and pore size of the soil treated with biological treatment were significantly reduced and the permeability rate was reduced. Hatami et al. ${ }^{14}$ studied the performance of a sodium bentonite admixture in preventing the seepage of a canal bed. With 
the experimental study, they proved that this admixture layer can successively serve as a seepage barrier as its swelling fills the pores or voids between the sand particles and effectively controls the seepage through the soil.

In this research, we introduce a new anti-seepage material, i.e., the Sidraton particles, and study its performance in the leakage control. The Sidraton particles are a kind of composite material. They are produced by mixing bentonite, quartz particles and a polymer binder. By dispersing these particles on the inlet of a leakage, we form an artificial layer. This layer functions as an anti-seepage blanket as soon as the particles become hydrated and coherent due to their contact with water. We implement a set of experiments in this study to investigate the permeability characteristics of the anti-seepage blanket.

\section{EXPERIMENTAL PART}

\subsection{Materials}

Figure 1a shows Sidraton particles in their natural state. The particles are mainly composed of the core and the coating. The coating mainly includes bentonite and a polymer binder with a thickness of about $0.5 \mathrm{~mm}$ under a dry condition. The core is natural quartz made from crushed rocks such as granite and limestone, with a particle size of 5-10 mm. In the production of Sidraton particles, three steps are required. The first step is selecting the quartz. Source rocks with a high rigidity, bearing capacity and durability are the optimal choice for the core. The next step is mixing the quartz core with the outer coating. The materials are mixed in a blender for about 30 minutes. The final step is drying the mixture and then particles are produced. The produced Sidraton particles are eco-friendly because all the materials utilized are natural.

The particle-size distribution of the materials is plotted in Figure 2. It shows that the diameter of the particles mainly ranges from $5.0 \mathrm{~mm}$ to $10.0 \mathrm{~mm}$. The particle size influences the performance of the particles. When the particle size is relatively small (e.g., smaller than $5 \mathrm{~mm}$ ), the permeability resistance is poor because

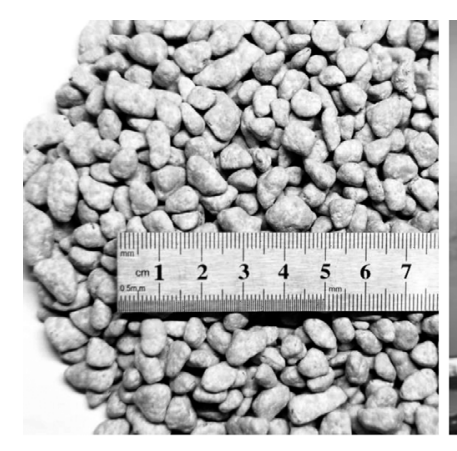

(a)

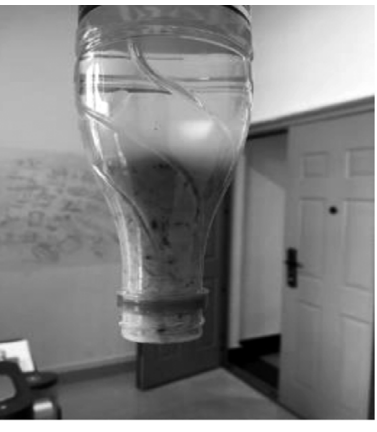

(b)
Figure 1: Photograph of Sidraton particles: a) their natural state, b) after hydration it is difficult to evenly wrap the coating around all the particles during the production of the particles. Moreover, small particles are prone to loss and failing to form the anti-seepage structure. On the contrary, if the particle size is too large, e.g., larger than $10.0 \mathrm{~mm}$, the permeability resistance will also decrease because there are large pores among the particles. The size of the Sidraton particles expand by $20 \%$ after absorbing water. This means that the particles with a size of more than $10 \mathrm{~mm}$ still have large pores after their expansion. The previous applications of the particles prove that the particles with their size ranging from $5.0 \mathrm{~mm}$ to $10.0 \mathrm{~mm}$ exhibit better comprehensive performance than those with smaller or larger sizes.

Before the expansion, the color of the particles is white when there are in a dry state. And the color becomes gray if the particles meet moisture. Besides the color changing, the particles swell and bond together when they meet water. This is because the Sidraton parti-

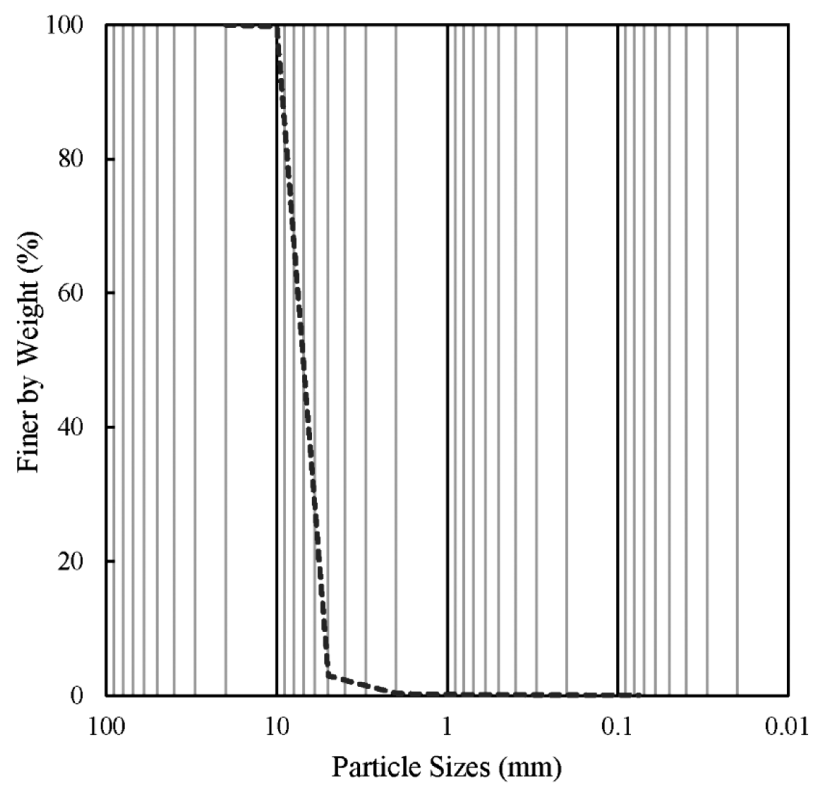

Figure 2: Gradation curve of Sidraton particles

Table 1: Basic physical parameters of Sidraton particles

\begin{tabular}{|l|c|c|}
\hline \multicolumn{1}{|c|}{ Parameters } & Loose state & Dense state \\
\hline $\begin{array}{l}\text { Density in its natural state } \rho \\
\left(\mathrm{g} / \mathrm{cm}^{3}\right)\end{array}$ & 1.3082 & 1.4861 \\
\hline Density in the dry state $\rho_{\mathrm{d}}\left(\mathrm{g} / \mathrm{cm}^{3}\right)$ & 1.2747 & 1.4480 \\
\hline Natural bulk density $\gamma\left(\mathrm{kN} / \mathrm{m}^{3}\right)$ & 12.8204 & 14.5638 \\
\cline { 2 - 3 } & 12.4921 & 14.1904 \\
\hline $\begin{array}{l}\text { Bulk density at saturation } \gamma_{\text {sat }} \\
\left(\mathrm{kN} / \mathrm{m}^{3}\right)\end{array}$ & 17.5224 & 18.5700 \\
\hline Void ratio $e$ & 1.0555 & 0.8087 \\
\hline Specific gravity $G_{\mathrm{s}}$ & 2.620 \\
\hline Free expansion rate $\delta_{e f}$ & \multicolumn{2}{|c|}{$20 \%$} \\
\hline$*$ Angle of internal friction $\varphi_{\mathrm{u}}\left({ }^{\circ}\right)$ & \multicolumn{2}{|c|}{30.95} \\
\hline$*$ Cohesive force $c_{\mathrm{u}}(\mathrm{kPa})$ & \multicolumn{2}{|c|}{27.57} \\
\hline
\end{tabular}

Note: $\varphi_{\mathrm{u}}$ and $c_{\mathrm{u}}$ are tested with the hydrated materials 
cles are a water-swellable material. The bentonite and the polymer-binder coating on the quartz core absorb moisture and then hydrate when they are wetted. The materials on the core swell and melt, cohering and filling the voids among the particles. Then the scatting particles form an anti-seepage blanket, functioning as a leakage barrier (Figure 1b). The physical characteristics of the particles are listed in Table $\mathbf{1 .}$

\subsection{Apparatus}

A pressure-controlled apparatus is designed to investigate the seepage behavior of Sidraton particles. The apparatus is composed of a loading chamber, a vertical loading system, a confining loading system, a water-supply system and a water-collecting system (Figure 3). The loading chamber is a hollow cylindrical tank where the sample is installed. A specimen with a diameter of $100.0 \mathrm{~mm}$ and a height of $200.0 \mathrm{~mm}$ is installed on the base pedestal. The base pedestal, the top cap on the specimen and a rubber film are utilized to isolate the specimen in the loading chamber. Both the base pedestal and the top cap are permeable. The base pedestal connects to the water-supply system. Pressure/volume controlled equipment can supply water to the bottom of the specimen with a precise target pressure or water head. Water spills freely through the specimen to the top of the specimen, and the hydraulic head on the specimen top can be treated as the constant equal to the altitude of the spilling water surface. This means that the head difference applied to the specimen is constant if the output pressure of the water-supply system is maintained as intended in the design of the apparatus. Moreover, the head difference is variable by adjusting the output of the pressure/volume controlled equipment. The water spilling from the top of the specimen flows into the water-collecting system monitoring the varying fluxes through the specimen. The weight of the water tank in the water-collecting system is recorded with a gravity sensor. The seepage flux is calculated by differentiating the relation between the accu-

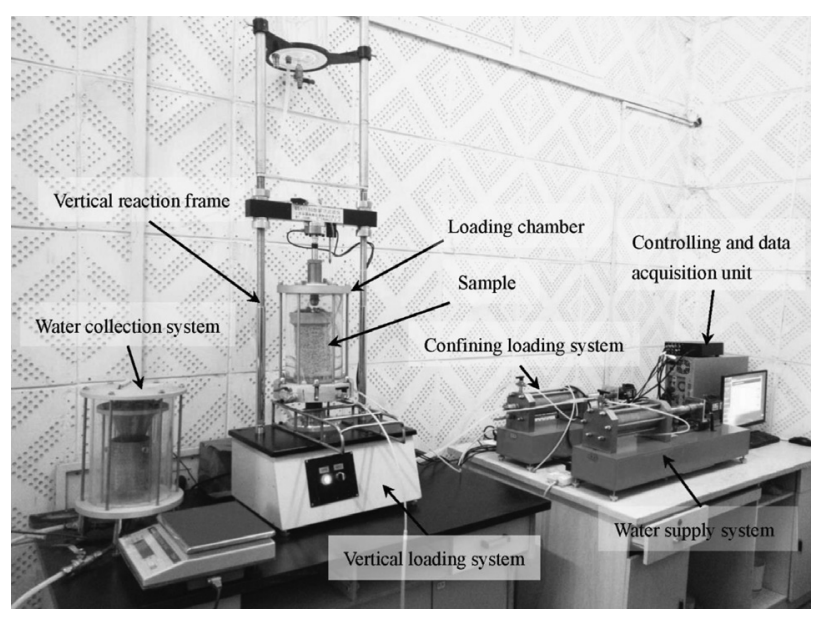

Figure 3: Photograph of the apparatus mulative weight of the collected water and the time, using the data received by the computer from the sensor.

The vertical loading system and the confining loading system supply target stress conditions to the specimen to investigate the seepage behavior under different stress states. The vertical loading system applies vertical loads to the bottom of the specimen via a hydraulic device and a vertical reaction frame. The values of the load and consequential deformation of the specimen are record and monitored by a loading sensor and a displacement sensor, respectively. The confining loading system applies the constant normal stress to the side and top of the specimen. The confining pressure is supplied and maintained via the other pressure/volume controlled equipment. Besides applying the confining load, the confining loading system, i.e., the pressure/volume controlled equipment, also evaluates the volumetric strain of the specimen by monitoring the volume of the water exchange with the loading chamber.

\subsection{Experiment procedure}

The experiments carried out in this study involve four main steps. The first step is the preparation of the specimens. The preparation is conducted in the loading chamber using a mold placed to the chamber prior to the specimen preparation. The particles are packed layer by layer with a depth of a layer of around $5.0 \mathrm{~cm}$. The porosity of a specimen is controlled to about 0.4 in the preparation step. The second step is the application of the stresses onto the specimen. At the beginning of this step, the mold used for preparing the specimen is removed and the specimen is sealed. The confining loading system then injects water into the chamber to drive the air out. The pressure/volume controlled equipment outputs the target stress on the specimen after the chamber is filled with water. The third step is the saturation of the specimen. The water-supply system is used to accomplish the saturation by slowly and continually filling water into the base pedestal. Accordingly, the voids in the specimen are filled by water as the water level rises. The water filling is terminated when the water lever reaches the top of the specimen. This process takes about $4.0 \mathrm{~h}$ to ensure sufficient saturation and hydration of the specimen. The fourth step is the seepage process. In this step, the water-supply system is employed to provide pressurized water to the bottom of the specimen via the pressure/volume controlled equipment. During the increase in the head difference, the accumulative weight of the water collected in the water-collecting system is recorded and used to calculate the varying of the permeability of the specimen.

\subsection{Experiment scenarios}

This study concentrates on the anti-seepage behavior of the Sidraton particles under different conditions. In the experiments, we investigate the effects of the stress 
state on the permeability of the blanket formed by the hydrated particles. Besides, in order to study the decrease of the permeability, we add sand to the Sidraton particles to evaluate the influence of the fraction of the sand on the hydraulic conductivity of the particles. The information about the experiments carried out in this study is summarized in Table 2 .

Table 2: Summary of the general information about the experiments carried out in the study

\begin{tabular}{|c|c|c|c|}
\hline No. & $\begin{array}{c}\text { Fraction of } \\
\text { sand } \%\end{array}$ & $\begin{array}{c}\text { Confining } \\
\text { pressure kPa }\end{array}$ & $\begin{array}{c}\text { Hydraulic gra- } \\
\text { dient }\end{array}$ \\
\hline$* 1$ & \multirow{6}{*}{0.0} & 0.0 & 1 \\
\hline 2 & & 25.0 & 1.0 \\
\hline 3 & & 30.0 & 1.25 \\
\hline 4 & & 40.0 & 1.75 \\
\hline 5 & & 50.0 & 2.25 \\
\hline 6 & & 60.0 & 2.5 \\
\hline 7 & \multirow{4}{*}{16.7} & 24.0 & 1.0 \\
\hline 8 & & 27.0 & 1.0 \\
\hline 9 & & 30.0 & 1.0 \\
\hline 10 & & 33.0 & 1.0 \\
\hline 11 & \multirow{4}{*}{23.1} & 24.0 & 1.0 \\
\hline 12 & & 27.0 & 1.0 \\
\hline 13 & & 30.0 & 1.0 \\
\hline 14 & & 33.0 & 1.0 \\
\hline 15 & \multirow{4}{*}{28.6} & 24.0 & 0.925 \\
\hline 16 & & 27.0 & 0.95 \\
\hline 17 & & 30.0 & 0.95 \\
\hline 18 & & 33.0 & 0.95 \\
\hline
\end{tabular}

Note: Experiment No. 1 is carried out with the traditional variable-head permeability-test method

\section{RESULTS}

\subsection{Hydraulic conductivity of the specimen}

The typical relations between the accumulative flow collected by the water-collecting system and the seepage time are plotted in Figure 4. This figure demonstrates the varying rate of the flow of experiments Nos. 1-4 under different stress conditions and hydraulic gradients. These four experiments are implemented with the specimens prepared only with the Sidraton particles. The scatter and fitted curves clearly reveal linear relations between the flow and the seepage time, indicating that the seepage behaviors of the materials obey Darcy's law. On the basis of Darcy's law, the hydraulic conductivities of these four specimens can be evaluated, combining them with the scale of the specimen, the flow rate and the hydraulic gradient.

Figure 5 shows the relations between the hydraulic conductivity and the confining stress. It shows that the magnitude of the hydraulic conductivity is $10^{-8} \mathrm{~cm} / \mathrm{s}$ if the specimen is under a stress-free condition. And the hydraulic conductivity decreases sharply when the confining stress is applied to the specimen. If the confining stress increases to $30.0 \mathrm{kPa}$, the magnitude of the hydraulic conductivity reaches $10^{-9} \mathrm{~cm} / \mathrm{s}$. Specifically, the
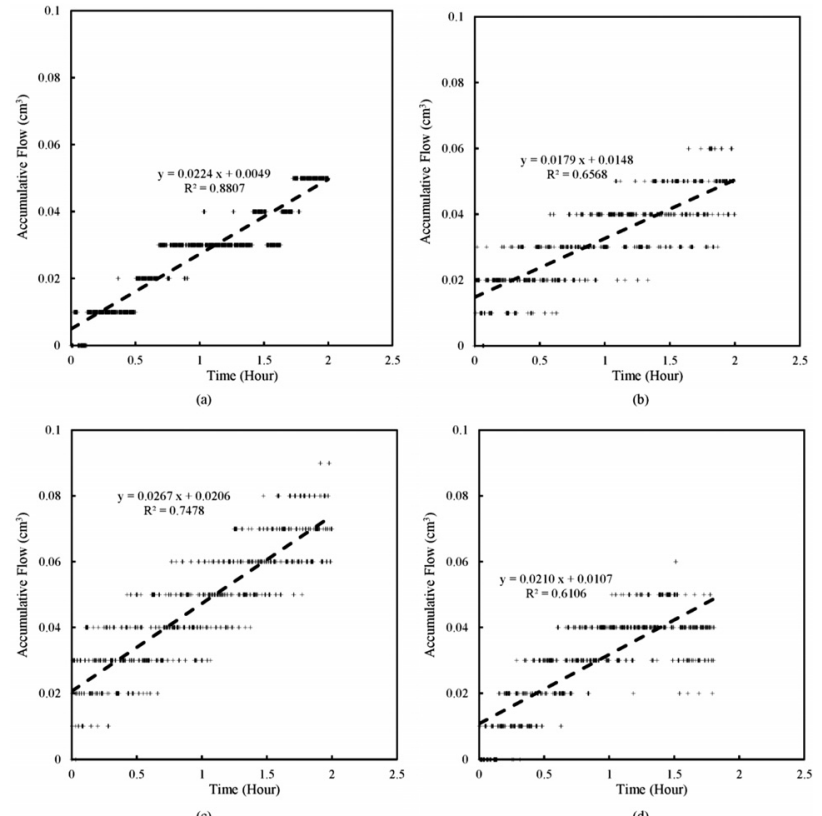

Figure 4: Relations between the accumulative flow and the seepage time for experiments No. $1-4$ : a) confining stress $=30.0 \mathrm{kPa}$ and hydraulic gradient $=1.25$, b) confining stress $=40.0 \mathrm{kPa}$ and hydraulic gradient $=1.75, \mathrm{c})$ confining stress $=50.0 \mathrm{kPa}$ and hydraulic gradient $=2.25$ and $\mathrm{d}$ ) confining stress $=60.0 \mathrm{kPa}$ and hydraulic gradient $=2.5$

permeability of the specimen significantly declines from $6.1 \times 10^{-8} \mathrm{~cm} / \mathrm{s}$ to $6.2 \times 10^{-9} \mathrm{~cm} / \mathrm{s}$ when the confining stress increases from $0.0 \mathrm{kPa}$ to $30.0 \mathrm{kPa}$, indicating a ten-time difference between these two stress conditions. But if the stress continuously increases, for example, from $30.0 \mathrm{kPa}$ to $60.0 \mathrm{kPa}$, the decrease of the permeability is gentle. The corresponding hydraulic conductivity declines from $6.2 \times 10^{-9} \mathrm{~cm} / \mathrm{s}$ to $2.6 \times 10^{-9} \mathrm{~cm} / \mathrm{s}$. This means that the decent rate is relatively high when the confining stress is low. When the stress increases, the

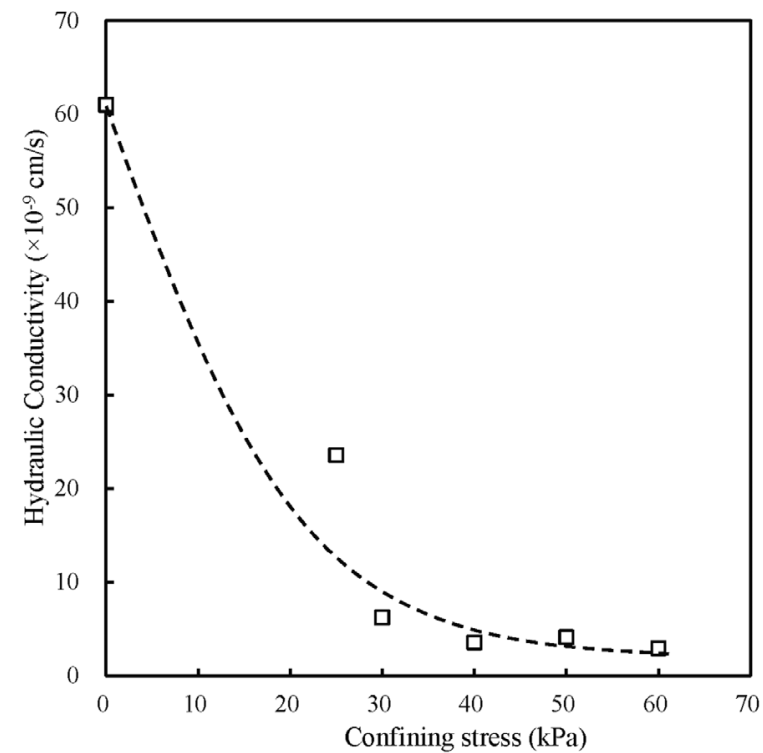

Figure 5: Relations between the hydraulic conductivity and confining stress 
rate of permeability decrease becomes gradual. And the hydraulic conductivity tends to be constant when the confining stress is relatively high.

\subsection{Influences of the sand fraction}

The experiment results indicate that the permeability of the anti-seepage blanket composed of the hydrated Sidraton particles is extremely low. In practice, for example, for an embankment-dam leakage repair, there is no need to use a material with an extremely low permeability since the embankment dams and levees allow slight leakage on the premise of safety. Therefore, in order to save materials and reduce costs, the constructors will mix a proportion of sand into the Sidraton particles when they carry out such projects.

In order to reveal the varying of the permeability of the anti-seepage blanket, we implement experiment Nos. $7-18$ to investigate the effects of the fraction of the sand mixed with the Sidraton particles. Moreover, we carry out the experiments under different stress conditions and similar hydraulic gradients to study the stress effects as well. In these experiments, we use different fractions of the sand to prepare the specimens. In the mixing procedure, we choose the common yellow sand to mix it with the Sidraton particles. This is because this sand has a low price while meeting the requirements of impermeability. The added sand can fill in the voids among the Sidraton particles. After wetting and expansion, the polymer binder and bentonite will wrap the sand as well. This means that the anti-leakage performance of the material will not be significantly reduced despite the fraction of sand added. Generally, if the average size of the sand particles is about $1 / 10$ of the size of the Sidraton particles, the material can be saved and the anti-leakage structure is still effective.

Figure 6 gives the variation in the hydraulic conductivity with the increase of the sand added to the Sidraton

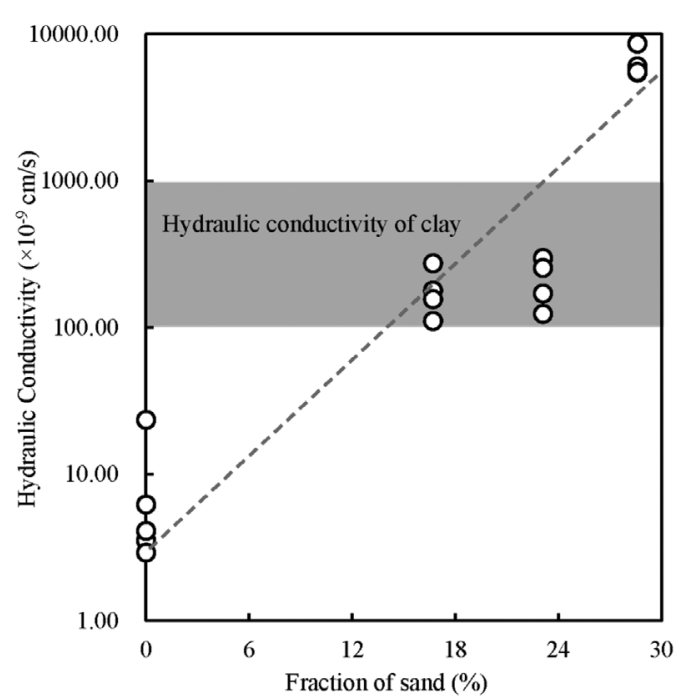

Figure 6: Variation in the hydraulic conductivity with the fraction of sand particles. It shows that if the proportion of sand in the mixed sample increases, the permeability of the specimen rises significantly. Contrary to the hydraulic conductivity of the material with pure Sidraton particles, the permeability increases exponentially when sand is added to the specimens. Mixing about $20.0 \%$ of sand leads to an about $100 \times$ increase in the permeability. It means that the anti-permeability of the mixed materials decreases notably. But the permeability of the mixed materials is still relatively low comparing to the natural anti-seepage materials. We also draw the range of the hydraulic conductivity of natural clay in Figure 6, represented by the blue area. It can be seen that the dots representing the hydraulic conductivities of the materials with sand fractions equal to $16.7 \%$ and $23.1 \%$, located in the blue area. This implies that the materials with sand fractions of less than $23.1 \%$ still exhibit the anti-seepage behavior equivalent to, or even better than, the behavior of natural clay.

\section{DISCUSSION}

The experiment results show that the Sidraton particles have the favorable anti-seepage ability after their hydration. Since the hydration time of the particles is relatively short, generally less than 1.0 hour, the impervious structure constructed with the Sidraton particles is highly effective in leakage-repair projects, including embankment dams and levees. The anti-permeability ability is due to the bentonite and the polymer-binder coating on the quartz core. The bentonite gives the expansibility to the particles when they absorb moisture. When the particles meet water, the bentonite hydrates and expands, filling in the pores among the particles. This process turns a granular material into an anti-seepage one since the voids in the material are fully filled. Moreover, if the bentonite softens when it meets water under a relatively high confining stress, the filling degree for the pores should be much higher than in the conditions with low confining stresses. The anti-seepage performance of the Sidraton particles is significantly improved when the confining stress is applied. This is the reason why the hydraulic conductivity declines with the increase in the confining stress, as demonstrated in Figure 5. This behavior indicates that the strengthening of the stress condition is an effective way to enhance the performance of the Sidraton particles used in leakage-repair projects.

The special composition of the Sidraton particles yields several advantages over the traditional anti-seepage methods. Firstly, the impermeability is much higher than that of natural clay, which is widely used as the impervious curtain in dam constructions. Figure 6 shows that the hydraulic conductivity of the hydrated Sidraton particles is less than $1 \%$ of the permeability of clay. This implies that the amount of the material requirement is much lower if the Sidraton particles replace, or partly replace, clay. Additionally, the permeability of the hy- 
drated Sidraton particles is still equivalent to, or better than, natural clay even when sand is mixed with them. Therefore, the cost of Sidraton particles can be significantly reduced by adding sand to them, on the premise that they exhibit an anti-seepage performance similar to that of natural clay. Their second advantage is that Sidraton particles have the ability to coordinatedly deform with the structure. The hydraulic structure of embankment dams and levees may deform because of the surrounding effects such as earthquakes and floods. If the anti-seepage body is incapable of deforming synchronously with the structure, the anti-seepage construction will be damaged and even lose its efficacy. The hydrated Sidraton particles can synchronously deform with the structure. This is because the anti-seepage blanket composed of the Sidraton particles can remain plastic when it meets water. The hydrated bentonite and polymer binder on the particles make the blanket deformable during its full life cycle.

The third advantage is the self-repairing ability. Besides clay, the HDPE film is another common material used in anti-seepage projects, especially in landfill constructions. The HDPE film is extremely impervious; its permeability can be as low as $10^{-14} \mathrm{~cm} / \mathrm{s}$. A $2.0 \mathrm{~mm}$ film can fulfil the seepage-proofing requirements for landfill constructions. But the vital problem of the HDPE film is potential damage in the construction and operation processes. Moreover, the damage to the film has been proved to be very common in practice. The consequences of the HDPE-film damage are severe since the film is probably unrepairable once the construction is completed. Contrastingly, the damage of an anti-seepage structure composed of the Sidraton particles is much less serious. This is because the materials on the Sidraton particles can swell after they meet water. And the coating on the cores of the particles is fluxible owing to the polymer binder. Therefore, once damages, e.g., cracks and punctures, occur in an anti-seepage structure, the hydrated bentonite and polymer binder will fill in the damages automatically, stopping their progression and maintaining the anti-seepage ability.

\section{CONCLUSIONS}

In this study, a set of laboratory experiments is conducted with a pressure-controlled apparatus to investigate the anti-seepage characteristics of the Sidraton particles. The experiments reveal the seepage behavior of the hydrated Sidraton particles under different stress conditions. The hydraulic conductivities of the specimens are calculated on the basis of Darcy's law. The effects of the stress condition and the fraction of the sand mixed with the materials are also studied.

The experiment results show that the hydrated Sidraton particles exhibit the favorable anti-seepage ability. The hydraulic conductivity of the hydrated Sidraton particles is about $6.1 \times 10^{-8} \mathrm{~cm} / \mathrm{s}$ under a stress-free con- dition. And the permeability declines to $6.2 \times 10^{-9} \mathrm{~cm} / \mathrm{s}$ if the confining stress increases to about $30.0 \mathrm{kPa}$. Besides the low permeability, the hydrated Sidraton particles are also proved to be stress sensitive. The hydraulic conductivity sharply decreases 10 times when the confining stress increases from $0.0 \mathrm{kPa}$ to $30.0 \mathrm{kPa}$. The permeability continuously declines if the confining stress keeps rising. But the rate of permeability decrease is gradual. And the hydraulic conductivity tends to be constant when the confining stress is relatively high. The effects of adding sand are also significant for the permeability of the hydrated particles. The experiments show that mixing about $20.0 \%$ of sand with the Sidraton particles will lead to an about $100 \times$ increase in the permeability. But the permeability of the mixed materials is still relatively low compared to the natural anti-seepage materials.

The advantages of an anti-seepage structure composed of the Sidraton particles are also confirmed via its comparison with the traditional leakage-proofing materials such as natural clay and the HDPE film. These advantages include an extremely low permeability, the coordinated-deformation ability and the self-repairing ability. Owing to these characteristics, the Sidraton-particle material can play an important role in anti-seepage projects including leakage repairs of embankment dams and levees.

\section{Acknowledgment}

This work was supported by the National Key R\&D Program of China (grant numbers 2018YFB1600400 \& 2018YFC1504700), the National Natural Science Foundation of China (grant number 41530640), the National Natural Science Foundation of Chongqing, China (grant number cstc2018jcyjAX0559) and the fund of China Geology Survey (grant number DD20189270).

\section{REFERENCES}

${ }^{1}$ J.-Y. Lee, Y.-K. Choi, H.-S. Kim, S.-T. Yun, Hydrologic characteristics of a large rockfill dam: Implications for water leakage, Eng. Geol., 80 (2005), 43-59, doi:10.1016/j.enggeo.2005.03.002

${ }^{2}$ T. Wang, J. Chen, P. Li, Y. Yin, C. Shen, Natural tracing for concentrated leakage detection in a rockfill dam, Eng. Geol., 249 (2019), 1-12, doi:10.1016/j.enggeo.2018.12.018

${ }^{3}$ A. Cividini, S. Bonomi, G. C. Vignati, G. Gioda, Seepage-Induced Erosion in Granular Soil and Consequent Settlements, Int. J. Geomech., (2009), 187-194, doi:10.1061/ASCE1532364120099:4187

${ }^{4}$ R. Fell, J. J. Fry, State of The Art on the Likelihood of Internal Erosion of Dams and Levees by Means of Testing, Eros. Geomech. Appl. to Dams Levees, (2013), 1-99, doi:10.1002/ 9781118577165.ch1

${ }^{5}$ W. S. Huang, S. J. Cai, W. X. Wang, Images of high density resistivity method in leakage detecting of the watertight screen at Gushan open-pit mine, in: Appl. Mech. Mater., Trans Tech Publ., 2013, 1167-1170, doi:10.2991/icsem.2013.99 
${ }^{6}$ Y.-F. Xue, X.-T. Sun, Y.-F. Sun, Transient electromagnetic resistivity imaging formation in detecting rock seepage passage, Hydrogeol. Eng. Geol., 31 (2004), 96-98

${ }^{7}$ T. K. T. Huotari-Halkosaari, J. M. Lerssi, Electrical resistivity tomography and transient electromagnetic survey in Luikonlahti tailings impoundment area, in: Near Surf. Geosci. 2012 - 18th Eur. Meet. Environ. Eng. Geophys., European Association of Geoscientists \& Engineers, 2012, cp-306, doi:10.3997/22144609.20143352

${ }^{8}$ I.-K. Cho, J.-Y. Yeom, Crossline resistivity tomography for the delineation of anomalous seepage pathways in an embankment dam, Geophysics, 72 (2007), G31-G38, doi:10.1190/1.2435200

${ }^{9}$ W. Mao, E. C. Yan, Y. B. Cao, S. L. Jiang, Simulation of landslide seepage field with the action of reservoir water fluctuations, Appl. Mech. Mater., Trans Tech Publ., (2011), 4802-4807, doi:10.4028/ www.scientific.net/amm.71-78.4802
${ }^{10}$ B. Lee, S. Oh, M.-J. Yi, Mapping of leakage paths in damaged embankment using modified resistivity array method, Eng. Geol., (2020), 105469, doi:10.1016/j.enggeo.2019.105469

${ }^{11}$ K. R. Dhawan, S. Burele, K. Bagwan, Curtain Grouting, a Tool Used for Stopping the Seepage from an Existing Dam, Indian Geotech. J., 49 (2019), 552-565, doi:10.1007/s40098-019-00355-9

${ }^{12}$ W. W. Müller, HDPE geomembranes in geotechnics, Springer, 2007

${ }^{13}$ Y. Gao, X. Tang, J. Chu, J. He, Microbially Induced Calcite Precipitation for Seepage Control in Sandy Soil, Geomicrobiol. J., 36 (2019), 366-375, doi:10.1080/01490451.2018.1556750

${ }^{14}$ F. Hatami, H. Gogonani, T. Masoud, Implementation of a dam wall by plastic concrete to control water seepage under soil dams structure, Eur. Online J. Nat. Soc. Sci. Proc., 4 (2016), 760 